\section{Study Action Research: Literasi Akuntansi UMKM Berbasis ETAP dan Android Pada Era Covid-19 Normal Baru}

\author{
Syahril Djaddang'., Sailendra, S2, M. Ardiansyah \\ Syam $^{3}$., Susilawati ${ }^{4}$, Nungki, P5 $^{5}$ \\ 1,2,3Sekolah Pascasarjana Magister Akuntansi, \\ ${ }^{4}$ Fakultas Ekonomi dan Bisnis, \\ ${ }^{5}$ Fakultas Pariwisata, Universitas Pancasila, Jakarta, \\ Indonesia
}

Received : 7/03/2021

Revised : 9/04/2021

Accepted : 1/05/2021

*Corresponding author

Syahril Djaddang ${ }^{1}$

Email : syahril@univpancasila.ac.id

\begin{abstract}
Abstraksi
Tujuan Pelaksanaan pengabdian pada masyarakat dan penelitian (action research) adalah mempercepat proses pengembangan budaya kewirausahaan; untuk meningkatkan pengetahuan UMKM dan Koperasi terhadap dunia digital yang berhubungan dengan literasi akuntansi berbasis ETAP dan Android melalui pelatihan, pendampingan dan penelitian terhadap para pelaku UMKM dan Koperasi di Kota Bogor. Pandemi Covid-19 normal baru dan disrupsi industri 4.0 telah merubah tatanan sosial-ekonomi, turut mempengaruhi jenis industri UMKM dan Koperasi saat ini, masih rendahnya literasi akuntansi dan tatakelola keuangan, ditambah dengan transformasi tatanan sosial-ekonomi dari sistem konvensional ke sistem digital. Metode pelaksanaan kegiatan program PKM dilaksanakan dalam bentuk pelatihan akuntansi koperasi dan UMKM berbasis Entitas Tanpa Akuntabilitas Publik (ETAP) dan Android, menempatkan satu orang mahasiswa untuk melaksanakan FGD pada koperasi dan UMKM tersebut untuk memfasilitasi pelaku koperasi dan UMKM dalam berinovasi dan meningkatkan kreatifitas benwirausaha yang mandiri sesuai dengan produk unggulan berbasis PSAK ETAP dan android di kota Bogor. Keunggulan IPTEK yang dimiliki semua wirausaha koperasi dan UMKM belum menerapkan PSAK ETAP Koperasi dan UMKM saat melakukan pencatatan dan pembukuan, seperti; membuat arus kas, laporan harian omset penjualan dan pembinaan pengembangan bisnis pada empat (4) wilayah di Kota Bogor. Implikasi hasil penelitian dan pengabdian kepada masyarakat (action research) telah dilaksanakan dengan pelatihan, pendampingan dan merekomendasikan oleh akademisi bersinergi dengan Dinas Koperasi dan UMKM, perlu terus dilakukan secara berkesinambungan, karena, dengan
\end{abstract}

pelatihan dan pendampingan yang berkesinambungan, literasi dan keterampilan akuntansi UMKM berbasis SAK ETAP dan berbasis teknologi digital Android dapat ditingkatkan, sehingga efisiensi dan kinerja usaha dapat tercapai. Terutama pada era pandemi Covid-19 normal baru, agar pelaku usaha UMKM tetap dapat eksis dan mampu berkompetisi dalam menghadapi persaingan usaha.

Kata Kunci: Action research, Efisiensi Kinerja Usaha, Digitalisasi Literasi Akuntansi UMKM berbasis ETAP dan Android, Covid-19 Normal baru

\begin{abstract}
The purpose of implementing community service and research (action research) is to accelerate the process of developing an entrepreneurial culture; to increase the knowledge of MSMEs and Cooperatives in the digital world related to ETAP and Android-based accounting literacy through training, mentoring and research on MSME and cooperative actors in Bogor City. The Covid-19 pandemic and industrial disruption 4.0 have changed the socio-economic order; it also affects this type of industry. One of the challenges faced by MSMEs and Cooperatives today is the low accounting literacy and financial governance, coupled with the transformation of the socioeconomic order from conventional to digital systems. One solution to increase the skill and knowledge of MSMEs and Cooperatives to the digital system related to accounting literacy and financial governance is through training, mentoring, and research. Pieces of training, mentoring, and research on MSMEs and Cooperative members are conducted by interacting directly through face-to-face and field observation. The implications of the results of this training, mentoring and study, recommend that the training and mentoring undertaken by academics in synergy with Cooperatives and MSMEs Government need to continue to be carried out on an ongoing basis. With continuous training and mentoring, literacy, and accounting skills based on SAK ETAP and financial governance based on Android, MSMEs can be improved to achieve the business's efficiency and performance. Especially in the era of the Covid-19 pandemic and the new normal, MSMEs are still available to exist and compete in the business competition.
\end{abstract}

Keywords: Action research, Business Performance Efficiency, Digitalization of MSME Accounting Literacy based on ETAP and Android, the new Covid-19 Normal.

(C) 2021 Penerbit LPPM UP. All rights reserved 


\section{PENDAHULUAN}

Realitas koperasi dan Usaha Mikro Kecil Menengah (UMKM) adalah sektor ekonomi nasional yang paling strategis dan menyangkut hajat hidup orang banyak sehingga menjadi tulang punggung perekonomian nasional. Koperasi dan UMKM juga merupakan kelompok pelaku ekonomi terbesar dalam perekonomian di Indonesia dan telah terbukti menjadi kunci pengaman perekonomian nasional dalam masa krisis kesehatan pandemic COVID-19 serta menjadi desiminator pertumbuhan ekonomi saat dan pasca krisis.

Koperasi dan UMKM sebagai pilar utama dalam mengembangkan sektor ekonomi kreatif akan memberikan dampak positip bagi kehidupan masyarakat dan mengingat wilayah kota Bogor sedang mengalami transformasi sosial yang begitu cepat dari usaha tradisional ke semi industri terutama koperasi dan UMKM. Disamping itu sarat akan sumber daya manusia yang berbakat dan kaya akan kreatifitas dan kualitas pelaku usaha koperasi dan UMKM. Prospek koperasi dan UMKM sangat besar dikarenakan kondisi ekonomi masyarakat kota Bogor yang sangat kondusif bagi pengembangan usaha kuliner, kerajinan dan produk olahan.

Usaha UMKM merupakan soko guru perekonomian kota Bogor selain koperasi. Hal ini dapat dibuktikan bahwa sebagian sektor UMKM pada 4 wilayah di kota Bogor Jawa Barat. Semakin berkembang ditengah kesibukan lalu lintas perdagangan di Jabodetabek. Perkembangan unit usaha koperasi dan UMKM dari tahun ke tahun semakin bertambah, Perkembangan ini terlihat dari sisi jumlah saja, khususnya aspek keuangan yang harus dipraktikkan sesuai dengan PSAK ETAP Koperasi dan UMKM untuk menigkatkan kinerja keuangannya. Upaya Pelaksanaan kegiatan program PKM dilaksanakan dalam bentuk pelatihan akuntansi koperasi dan UMKM berbasis ETAP dan Android. Pelatihan dilaksanakan untuk memberikan pengetahuan akuntansi yang berbasis ETAP koperasi dan UMKM, mendorong tumbuhnya motivasi berwirausaha, meningkatkan pemahaman manajemen serta membuat rencana bisnis atau studi kelayakan usaha. Pengalaman praktik kepada pelaku usaha koperasi dan UMKM dengan cara ikut mengelolah usaha sehari-hari pada unit usaha koperasi dan UMKM.

Keunggulan IPTEK yang dimiliki semua wirausaha tidak memadai atau belum menerapkan PSAK ETAP Koperasi dan UMKM saat melakukan pencatatan seperti; membuat arus kas tentang laporan harian hasil omset penjualan dan perkembangan operasi kegiatan usaha koperasi dan UMKM dan sekarang kondisi hanya menyewa tempat usaha yang dikelola oleh PEMDA dalam hal ini Dinas Koperasi dan UMKM tanpa pembinaan tentang pengembangan bisnis dan proses pencatatan berbasis PSAK ETAP koperasi dan UMKM. Adapun kesiapan Dinas Koperasi dan UMKM yang terkait secara fisik pelaksanaan kegiatan sudah siap, hanya pelatihan pencatatan hasil usaha berbasis PSAK ETAP koperasi dan UMKM masih perlu praktik penerapan pada semua koperasi dan UMKM di kota Bogor. Kondisi Wilayah di kota Bogor saat ini masih minimnya pembinaan pencatatan keuangan berbasis PSAK ETAP Koperasi dan UMKM yang relevan dengan permasalahan prioritas yang akan ditangani bersama, terutama meliputi bidang yang menjadi sumber persoalan prioritas untuk ditangani, misalnya bidang kuliner, kerajinan, Pariwisata dan lain-lain.

Permasalahan mitra dalam hal ini Dinas Koperasi dan UMKM untuk pembinaan literasi akuntansi keuangan berbasis PSAK ETAP koperasi dan UMKM dan android prioritas yang disepakati bersama untuk ditangani melalui program PKM di lingkungan Dinas koperasi dan UMKM kota Bogor. Adapun masalah utama yang dihadapi oleh pelaku koperasi dan UMKM adalah akses permodalan ke perbankan maupun lembaga nonperbankan lainnya (Abeng, 2015). Penyebabnya adalah ketidakmampuan pelaku usaha ekonomi kreatif dalam melakukan pencatatan dan menyajikan laporan keuangan secara baik dan benar berdasarkan prinsip akuntansi yang berlaku umum. Untuk itu pelatihan di bidang kewirausahaan dan dasar-dasar akuntansi perlu untuk dilakukan guna menginisiasi dan mendorong pertumbuhan kegiatan ekonomi kreatif berbasis kearifan lokal sehingga memiliki competitive advantage baik ditingkat nasional maupun global. Satari dan As'ad (2018), dalam penelitiannya menyimpulkan bahwa perlu dukungan dari semua stakeholder (pelaku ekonomi kreatif, institusi pendidikan, pemerintah daerah dan pemerintah pusat) untuk menciptakan ekosistem ekonomi kreatif di Indonesia. Institusi pendidikan dapat mengambil peran untuk memberikan pelatihan di bidang kewirausahaan dan dasar-dasar akuntansi dan proses bisnis lainnya guna menumbuhkan ekonomi kreatif di Indonesia berbasis android.

Keunggulan IPTEK yang dimiliki tidak memadai atau belum menerapkan PSAK ETAP koperasi dan UMKM saat melakukan pencatatan dan pembukuan seperti; membuat arus kas tentang laporan harian hasil omset penjualan dan perkembangan operasi kegiatan usaha dan sekarang kondisi hanya menyewa tempat usaha yang dikelola oleh tanpa pembinaan tentang pengembangan bisnis dan proses pencatatan berbasis PSAK ETAP koperasi \& UMKM berbasis android. 
Implikasi dari penerapan protokol kesehatan yang ketat tersebut, ternyata berdampak negatif terhadap kehidupan sosial serta ekonomi masyarakat, terutama sektor produksi dan distribusi. Dampak negatif sosial ekonomi dari PSBB karena pandemi Covid-19 tersebut, juga sangat memukul usaha kelompok industri mikro kecil dan menengah (UMKM) dan Koperasi. Sehingga berdasarkan survey yang dilakukan oleh ADB pada bulan September 2020 sebanyak 48,6 persen usaha UMKM di Indonesia tutup sementara dan penurunan permintaan domestik sebesar 30,5 persen (Antaranews.com, 2020b). Tak hanya itu, UMKM di Indonesia, mengalami permasalahan lain akibat dari pandemi, yaitu sulit mendapatkan bahan baku dan terhambatnya distribusi karena logistik yang tersendat akibat dari terbatasnya pergerakan orang dan barang. Hal tersebut berdampak terhadap turunnya permintaan in line dengan banyaknya pemutusan hubungan kerja (PHK) sehingga sangat berpengaruh terhadap omset dan pendapatan pelakU UMKM dan Koperasi, sehingga berdampak terhadap turunnya pendapatan dan daya belimasyarakat.

Namun demikian, walaupun dampak dari pengaruh pandemi covid-19 telah melemahkan kondisi perekonomian Indonesia secara umum, saat ini, sebagian besar UMKM yang ada masih tetap dapat eksis dan bertahan (Antaranews.com, 2020a) berkat kebijakan yang diberikan oleh pemerintah melalui bantuan UMKM, relaksasi pembayaran bunga kredit, dan akibat dari bertransformasinya para pelaku usaha dari sistem tradisional ke sistem digital, baik pemasaran, pola transaksi dan tatakelola keuangan yang dilakukan oleh pelaku usaha UMKM.

Tabel 1 Jumlah Usaha Mikro Kecil dan Menengah Menurut Kecamatan dan Bidang Usaha di Kota Bogor, Tahun 2020

\begin{tabular}{|c|c|c|c|c|c|c|}
\hline \multirow[b]{2}{*}{$\begin{array}{l}\text { Keca } \\
\text { matan }\end{array}$} & \multicolumn{6}{|c|}{ Bidang Usaha } \\
\hline & $\begin{array}{l}\text { Kuli } \\
\text { ner }\end{array}$ & $\begin{array}{l}\text { Pak } \\
\text { aian }\end{array}$ & $\begin{array}{l}\text { Pendi } \\
\text { dikan }\end{array}$ & $\begin{array}{l}\text { Oto } \\
\text { moti } \\
f\end{array}$ & $\begin{array}{l}\text { Agro } \\
\text { bisnis }\end{array}$ & $\begin{array}{l}\text { Jarin } \\
\text { gan } \\
\text { Inter } \\
\text { net }\end{array}$ \\
\hline (1) & (2) & (3) & (4) & (5) & (6) & (7) \\
\hline $\begin{array}{l}010 \\
\text { Bogor } \\
\text { Selata } \\
n\end{array}$ & $\begin{array}{l}1.2 \\
39\end{array}$ & 571 & 344 & 346 & 335 & 270 \\
\hline $\begin{array}{l}020 \\
\text { Bogor } \\
\text { Timur }\end{array}$ & 824 & 368 & 224 & 219 & 224 & 186 \\
\hline $\begin{array}{l}030 \\
\text { Bogor } \\
\text { Utara }\end{array}$ & $\begin{array}{l}3.2 \\
41\end{array}$ & $\begin{array}{l}1.47 \\
3\end{array}$ & 870 & 875 & 867 & 743 \\
\hline $\begin{array}{l}040 \\
\text { Bogor } \\
\text { Tenga } \\
\text { h }\end{array}$ & $\begin{array}{l}2.0 \\
07\end{array}$ & 902 & 554 & 543 & 552 & 440 \\
\hline
\end{tabular}

\begin{tabular}{|l|l|l|l|l|l|l|}
\hline $\begin{array}{l}\text { 050 } \\
\text { Bogor } \\
\text { Barat }\end{array}$ & $\begin{array}{l}1.2 \\
20\end{array}$ & 533 & 330 & 318 & 334 & 272 \\
\hline $\begin{array}{l}\text { O60 } \\
\text { Tanah } \\
\text { Sereal }\end{array}$ & 983 & 465 & 274 & 284 & 258 & 218 \\
\hline $\begin{array}{l}\text { Kota } \\
\text { Bogor }\end{array}$ & $\begin{array}{l}\mathbf{9 . 5} \\
\mathbf{1 4}\end{array}$ & $\begin{array}{l}\mathbf{4 . 3 1} \\
\mathbf{2}\end{array}$ & $\mathbf{5 . 5 9 6}$ & $\begin{array}{l}\mathbf{2 . 5 8} \\
\mathbf{5}\end{array}$ & $\mathbf{2 . 5 7 0}$ & $\begin{array}{l}\mathbf{2 . 1 2} \\
\mathbf{9}\end{array}$ \\
\hline
\end{tabular}

Sumber: BPS Kota Bogor, 2020; Sailendra, S., dan Syahril Djaddang., (2021)

Masih rendahnya literasi akuntansi UMKM berbasis PSAK ETAP dan android yang dimiliki oleh pelaku usaha UMKM kota Bogor, serta pengetahuan penguasaan teknologi akuntansi keuangan berbasis android juga masih lemah. Menjadikan pengabdian kepada masyarakat dan pelatihan ini sangat penting untuk dilakukan. Melalui pelatihan, pendampingan dan penelitian, merupakan salah satu jalan untuk meningkatkan keunggulan yang harus dimiliki oleh pelaku UMKM, agar usaha yang mereka kelola dapat menjadi lebih efisien guna meningkatkan kinerja usaha, sehingga dapat terus bertahan dan eksis, selama pandemi Covid-19 berlangsung guna mempersiapkan diri menyongsong masa normal baru, setelah masa pandemi berakhir. Karena dukungan digitalisasi dapat mendorong UMKM agar tetap terus bertahan untuk berkembang, sehingga menjadi penyokong ekonomi negara utamanya di masa pandemi Covid-19 (PikiranRakyat.com, 2021b); Sailendra, S., dan Syahril Djaddang., dkk (2021).

Tujuan Pelaksanaan pengabdian kepada masyarakat adalah mempercepat proses pengembangan budaya kewirausahaan; untuk meningkatkan pengetahuan UMKM dan Koperasi terhadap dunia digital yang berhubungan dengan literasi akuntansi dan tatakelola keuangan yaitu melalui pelatihan, pendampingan dan penelitian terhadap para pelaku UMKM dan Koperasi di Kota Bogor.

\section{METODE PELAKSANAAN}

Pengabdian pada masyarakat ini dilaksanakan dalam bentuk pelatihan, pendampingan dan penelitian lapangan, dilaksanakan dengan tatap muka, berinteraksi secara langsung dengan pelaku usaha dan observasi lapangan, menggunakan metode penelitan tindakan (action research). Menurut (Syam, Djaddang, Salim, \& Rachbini, 2020) Action research merupakan salah satu cara yang dilakukan dalam melakukan penelitian yang mendeskripsikan, menginterpretasikan dan kemudian dijelaskan oleh peneliti atas situasi yang ada sebagaimana adanya. Metode ini digunakan untuk mendapatkan gambaran secara utuh terhadap permasalahan dan hambatan yang dihadapi oleh para pelaku Koperasi dan UMKM, sehingga dapat dilakukan intervensi dan modifikasi sesuai dengan 
tujuan guna dilakukan perbaikan. Sehingga, permasalahan dan hambatan yang dihadapi oleh para pelaku usaha Koperasi dan UMKM didapatkan solusinya.

Pelaksanaan pengabdian masyarakat, terhadap pelaku usaha UMKM dan Koperasi, dilaksanakan atas sinergi dari para akademisi (dalam hal ini dilaksanakan oleh Sekolah Pascasarjana Magister Akuntansi Universitas Pancasila, Fakultas Ekonomi dan Bisnis Universitas Pancasila serta Fakultas Pariwisata Universitas Pancasila) bekerjasama dengan Kantor Dinas Koperasi dan UMKM Kabupaten Bogor, meliputi pelatihan, pendampingan dan penelitian terhadap tatakelola keuangan dan penyajian hasil usaha berdasarkan PSAK ETAP berbasis teknologi digital Android, mencakup langkah-langkah pelaksanaan pengabdian sebagai berikut:

a. Metode pendekatan Forum Group Diskusi (FGD) yang dapat diterapkan, seperti: pelatihan pencatatan sesuai PSAK ETAP Koperasi dan UMKM dengan teknologi berbasis Android. Pola pembimbingan, pengawasan terhadap tenant, pola pemberian bantuan teknologi dan metode penyelesaian masalah dengan metode pencatatan PSAK ETAP Koperasi dan UMKM berbasis teknologi digital Android.

b. Kemungkinan adanya kolaborasi dengan Dinas Koperasi dan UMKM. Kolaborasi dengan lembaga profesi Ikatan Akuntan Publik Indonesia dalam hal pelatihan metode pencatatan PSAK ETAP Koperasi dan UMKM berbasis teknologi digital Android.

c. Rencana pengembangan pengabdian kepada masyarakat pada tahun-tahun selanjutnya, dengan pengembangan unit usaha kreatif yang dapat dikoordinir langsung oleh Tim Pengabdian pada Masyarakat, bekerjasama dengan Dinas Koperasi dan UMKM pada empat wilayah dalam menerapkan standar PSAK ETAP Koperasi dan UMKM berbasis teknologi digital Android untuk wilayah wirausaha kreatif Koperasi dan UMKM di Kota Bogor.

Pengabdian kepada masyarakat ini, dilakukan dalam situasi pandemi virus Covid-19 yang sedang melanda dunia. Namun demikian, dengan menjaga protokol kesehatan yang ketat, acara ini dapat dilakukan secara tatap muka, dengan peserta yang dibatasi sebanyak dua puluh pelaku usaha UKM, dengan melakukan kunjungan ke lokasi tempat pengabdian masyarakat dilaksanakan, di kota Bogor, Jawa Barat. Kegiatan pengabdian kepada masyarakat ini dilaksanakan pada tanggal 26 Agustus 2020. Secara terstruktur, metode pelaksanaan kegiatan pengabdian kepada masyarakat, dilakukan sebagai berikut: a. Pemaparan materi dengan topik "Standar Akuntansi Koperasi berbasis ETAP dan Standar Akuntansi Keuangan EMKM"

b. Penjelasan mengenai Akuntansi UKM dan Koperasi Serba Usaha berbasis android disertai dengan contoh perhitungan pajaknya.

c. Penjelasan mengenai Aplikasi Akuntansi Koperasi Usaha Serba Ada;

d. Menyebarkan Kuesioner terkait dengan profil peserta, profil usaha, dan kegiatan pelaporan keuangan berbasis ETAP dan Android;

e. Diskusi dan tanya jawab terkait kegiatan pelaporan keuangan berbasis ETAP dan Android;

f. Fokus Group Discussion (FGD) dengan para pelaku Koperasi dan UMKM di Kota Bogor

Kegiatan pengabdian kepada masyarakat, pendampingan dan penelitian ini dilakukan dengan metode interaksi dua arah dengan pelaku usaha dan observasi lapangan. Kemudian dilanjutkan dengan penjelasan atas laporan laba rugi untuk Koperasi dan UMKM oleh para nara sumber. Kemudian, pada kesempatan yang sama diberikan waktu untuk melakukan interaksi tanya jawab antara peserta dan narasumber. Hasil dari pengabdian masyarakat ini, merupakan bahan masukan untuk sebagai program penelitian dan pengabdian masyarakat, guna memberikan solusi terhadap masalah yang dihadapi oleh Koperasi dan UMKM pada umumnya, serta masyarakat Kota Bogor, khususnya.

\section{PEMBAHASAN}

Pengelolaan data keuangan berbasis android yang didesain sedemikian rupa agar bisa menjadi sarana untuk pengumpulan, pengelolaan, penyajian dan referensi, serta proses komunikasi data atau informasi keuangan. Indikator adalah sebagai berikut: (a), Komputerisasi proses akuntansi merupakan sistem akuntansi dimana aplikasi yang dijalankan digunakan untuk mengolah transaksi akuntansi serta mampu menghasilkan laporan keuangan yang dibutuhkan. (b), Pengolahan data transaksi keuangan yang digunakan harus berdasarkan Software yang sesuai dengan undang-undang yang berlaku. (c) Terintegrasinya pembuatan laporan akuntansi dan manajerial serta adanya output laporan akuntansi berdasarkan sistem informasi yang terintegrasi. Penyajian Laporan Keuangan Laporan keuangan merupakan struktur yang menyajikan posisi keuangan dan kinerja keuangan dalam sebuah entitas. Tujuan umum dari laporan keuangan ini untuk kepentingan umum adalah penyajian mengenai posisi keuangan, kinerja keuangan, dan arus kas dari entitas yang sangat berguna untuk membuat keputusan ekonomis bagi para penggunanya. Untuk dapat mencapai tujuan ini, laporan keungan menyediakan informasi mengenai elemen dari entitas yang terdiri dari aset, 
kewajiban, networth, beban, dan pendapatan (termasuk gain dan loss) perubahan ekuitas dan arus kas. Informasi tersebut diikuti dengan catatan akan membantu pengguna memprediksi arus kas masa depan. (Ikatan Akuntansi Indonesia, 2012). Tujuan laporan keuangan adalah menyediakan informasi posisi keuangan, kinerja keuangan dan laporan arus kas suatu entitas yang bermanfaat bagi sejumlah besar pengguna dalam pengambilan keputusan ekonomi pihak internal maupun eksternal. Dalam memenuhi tujuannya, laporan keuangan juga menunjukkan apa yang telah dilakukan manajemen atau pertanggung jawaban pihak manajemen atas sumber daya yang dipercayakan kepadanya.

Disrupsi industri 4.0, kemudian disusul dengan terjadinya pandemi Covid-19 dan era baru. Mengakibatkan perubahan secara signifikan terhadap tatanan kehidupan sosial, budaya dan ekonomi masyarakat, dari sistem konvensional menjadi berbasis digital. Transformasi dari sistem konvensional ke sistem digital tersebut, tidak terlepas mempengaruhi sektor industri Koperasi dan UMKM. Tidak terkecuali, sistem tatakelola keuangan dari tradisional bertransformasi menjadi berbasis teknologi digital Android. Dampak transformasi tersebut, secara umum dirasakan dan berpengaruh bagi para pelaku usaha UMKM di Kota Bogor.

Pengabdian pada masyarakat ini, dilaksanakan pada tanggal 26 Agustus 2020. Sedangkan pelatihan, pendampingan dan penelitian ini, dengan mempertimbangkan kemudahan, jarak dan efisiensi di pusatkan di Kantor Dinas Koperasi dan UMKM Kota Bogor. Peserta PKM di ikuti sebanyak dua puluh satu orang, yang berasal dari Kota Bogor, provinsi Jawa Barat. Terdiri dari UMKM dan usaha yang dirintis sendiri yang tersebar di sekitar wilayah Kota Bogor, antara lain dari Bogor Tengah, Bogor Barat, Bogor Timur, Bogor Utara, Bogor Selatan dan sekitarnya.

Berdasarkan hasil observasi lapangan, yang dilakukan dengan metode wawancara langsung dan pengisian kuesioner oleh peserta pelatihan PKM yang dipandu oleh narasumber dan pendamping, didapat data dan profil peserta pelatihan UMKM Kota Bogor, sebagai berikut:

Tabel 2 Statistik Deskriptif Penelitian

\begin{tabular}{|l|l|l|l|l|l|}
\hline KETERANGAN & N & Min & Max & Mean & $\begin{array}{l}\text { S. } \\
\text { Dev }\end{array}$ \\
\hline Umur & 21 & 22 & 55 & 41 & 9.49 \\
\hline Modal (Juta) & 21 & 5 & 500 & 15 & 115 \\
\hline $\begin{array}{l}\text { Omzet } \\
\text { (Juta/Thn) }\end{array}$ & 21 & 5 & 400 & 14 & 97 \\
\hline $\begin{array}{l}\text { Keuntungan } \\
\text { (Juta/Thn) }\end{array}$ & 21 & 5 & 100 & 13 & 30 \\
\hline SAK ETAP & 21 & 0 & 0 & 0 & 0 \\
\hline Android & 21 & 0 & 0 & 0 & 0 \\
\hline
\end{tabular}

Sumber: Diolah untuk penelitian ini (2021)

Keterangan: Umur = Umur peserta dalam tahun; Modal = Jumlah modal usaha dalam rupiah; Omzet = rata-rata jumlah omzet per-tahun dalam rupiah; Keuntungan = Jumlah rata-rata keuntungan pertahun dalam rupiah; SAK ETAP = Jumlah pelakU usaha yang telah melaksanakan pembukuan berbasis SAK ETAP; Android = Jumlah pelaku usaha yang telah melakukan pembukuan berbasis digitalandroid.

Pelatihan PKM, di ikuti langsung oleh pimpinan atau pemilik usaha UMKM. Dari dua puluh satu peserta yang hadir terdiri dari $98 \%$ peserta wanita dan $2 \%$ merupakan pelaku usaha UMKM berjenis kelamin pria. Jumlah peserta yang hadir untuk periode ini, sengaja dibatasi, karena pelatihan diadakan pada saat masih berlangsungnya pandemi Covid-19 dengan menjalankan protokol kesehatan yang ketat. Umur pelaku usaha UMKM yang mengikuti pelatihan, dengan rentang usia antara 22 tahun sampai dengan 55 tahun, namun demikian sebagian besar pelaku usaha UMKM yang mengikuti pelatihan rata-rata berumur 41 tahun. Sedangkan tingkat pendidikan pelaku usaha UMKM, terendah adalah Sekolah Menengah Atas (SMA) sederajat, namun demikian terdapat pengusaha UMKM yang memiliki tingkat pendidikan Diploma Tiga, Strata Satu bahkan Strata Dua. Berdasarkan data yang ada, pelaku usaha UMKM di Kota Bogor dikelola oleh pemilik yang memiliki usia yang produktif, hal ini membuktikan bahwa, jenis usaha UMKM menyerap tenaga kerja di sektor informal, sebagaimana dibuktikan secara empiris dari berbagai hasil penelitian yang ada. Sedangkan tingkat pendidikan pelaku usaha UMKM dengan pendidikan paling rendah dengan tingkat sekolah menengah atas sederajat, bahkan terdapat pelaku usaha dengan pendidikan Diploma, Strata Satu bahkan Strata Dua, juga membuktikan bahwa, sektor industri UMKM, merupakan jenis pekerjaan yang layak dipertimbangkan dengan penghasilan dan memiliki masa depan yang menjanjikan, sebagai alternatif pilihan profesi atau pekerjaan. Karena sangat terbatas ketersediaan lapangan pekerjaan di sektor formal yang dapat disediakan oleh pemerintah, menjadi pengusaha dan pemilik UMKM menjadi solusi, untuk mengatasi dan menyerap lonjakan tenaga kerja, yang dari tahun ke tahun menjadi masalah bagi pemerintah dan pencari kerja, khususnya pencari kerja angkatan muda. Pelaku usaha dengan usia yang produktif dengan memiliki pendidikan yang cukup tinggi, diharapkan dapat menerima serta memahami materi yang disampaikan oleh nara sumber dengan lebih baik, sehingga penguasaan literasi akuntansi SAK ETAP dan tatakelola keuangan 
berbasis Android, dapat menambah keunggulan penguasa UMKM untuk berkompetisi, khususnya dalam mengakses permodalan dari perbankan dan lembaga keuangan.

Berdasarkan jenis usaha, sesuai dengan data statistik yang dipublikasikan oleh Pemerintah Kota Bogor tahun 2019, sebagian besar pelaku usaha UMKM di Kota Bogor adalah pelaku usaha industri Kuliner (BPS Kota Bogor, 2019). Hal tersebut tercermin dari jumlah peserta yang mengikuti pelatihan. Kelompok jenis usaha yang terbesar adalah UMKM Kuliner, kemudian disusul oleh

Tabel 3: Daftar peserta PKM di Dinas Koperasi dan UMKM kota Bogor

\begin{tabular}{|c|c|c|c|}
\hline No. & UMKM/Dirintis Sendiri & Nama Usaha & Jenis kelamin/Jabatan/Umur \\
\hline 1 & $\begin{array}{l}\text { Kuliner Pecel Ayam \& } \\
\text { kripik tempe }\end{array}$ & A \& L Food & Wanita/Pimpinan Usaha/30 thn \\
\hline 2 & Produksi Makanan & Dapoer Rendang & Pria/Pimpinan Usaha/31 thn \\
\hline 3 & Kuliner (Bumbu Racik) & Rempah Indonesia & Wanita/Pimpinan usaha/45 thn \\
\hline 4 & Makanan Ringan & $\begin{array}{lll}\text { Kripik } & \text { Pete \& } \\
\text { Jengkol } & & \\
\end{array}$ & Wanita/Pimpinan Usaha/46 thn \\
\hline 5 & Keset \& Kuliner & Siti Keset \& Krupuk & Wanita/Pimpinan Usaha/52 thn \\
\hline 6 & Kuker, Sayon Bakar, Donat & Ciboga Produk & Wanita/Pimpinan Usaha/51 thn \\
\hline 7 & Rajutan & Tas Rajutan & Wanita/Pimpinan Usaha/41 thn \\
\hline 8 & Kue & Cireng Padalarang & Wanita/Pimpinan Usaha/51 thn \\
\hline 9 & Snack, Cake \& Cookies & Rumah Engi & Wanita/Pimpinan Usaha/47 thn \\
\hline 10 & Kuliner & $\begin{array}{l}\text { Nick Nack Frozen } \\
\text { Food }\end{array}$ & Wanita/Pimpinan Usaha/49 thn \\
\hline 11 & Makanan & $\begin{array}{l}\text { INDE CAKES \& } \\
\text { COOKIES }\end{array}$ & Wanita/Pimpinan Usaha/37thn \\
\hline 12 & Kue Kering & $\begin{array}{l}\text { Pekka Yasmin/Telur } \\
\text { Gabus Keju }\end{array}$ & Wanita/Pimpinan Usaha/55 thn \\
\hline 13 & Makanan \& Minuman Olahan & $\begin{array}{l}\text { Batogor Banjir Si } \\
\text { Sadun }\end{array}$ & Wanita/Pimpinan Usaha/25 thn \\
\hline 14 & Makanan Ringan & Magoda & Wanita/Pimpinan Usaha/34 thn \\
\hline 15 & Makanan & FIEFIE FOOD & Wanita/Pimpinan Usaha/41 thn \\
\hline 16 & Bunga Stoking & Marsyiatun & Wanita/Pimpinan Usaha/41 thn \\
\hline 17 & Kuliner & Berkah Saiyo & Wanita/Pimpinan Usaha/43 thn \\
\hline 18 & Konveksi Gamis Anak & Rumah Kreatif & Wanita/Pimpinan Usaha/43 thn \\
\hline 19 & Minuman & Paradice Coffee & Pria/Pimpinan Usaha/22 thn \\
\hline 20 & Minuman & Susu Kurma & Wanita/Pimpinan Usaha/26 thn \\
\hline 21 & Kuliner/Minuman & $\begin{array}{l}\text { Mamicha Pastry \& } \\
\text { Chococha Coklat }\end{array}$ & Wanita/Pimpinan Usaha/44 thn \\
\hline
\end{tabular}

Sumber: Data diolah (Oktober, 2020)

kelompok usaha jenis Souvenir dan kemudian jenis industri lainnya. Modal usaha pelaku UMKM dengan nilai terendah lebih dari 5 juta rupiah, sedangkan nilai tertinggi mencapai 500 juta rupiah. Berdasarkan rata-rata, terdapat sekitar $80 \%$ dari pelaku usaha UMKM memiliki modal usaha antara 5 juta sampai dengan 190 juta rupiah.

Sedangkan omset usaha, para pelaku UMKM memiliki omset terendah berkisar 10 juta rupiah sampai dengan 99 juta rupiah, bahkan terdapat dua usaha kuliner yang memiliki omset diatas 100 juta sampai dengan 400 juta rupiah per tahun. Rata-rata keuntungan yang diperoleh berada diatas 4 juta rupiah sampai dengan 12 juta rupiah pertahun. Namun demikian terdapat empat usaha UMKM yang bergerak dibidang kuliner, mendapatkan keuntungan diatas 20 juta sampai dengan 100 juta rupiah per tahun. Hal ini membuktikan bahwa jenis usaha industri UMKM, memiliki prospek yang baik dan menjanjikan, untuk 
eksis untuk dapat menunjang dan menjadi sebagai salah satu pilar ekonomi nasional, dapat terwujud.

Peserta PKM berasal dari Kota Bogor Provinsi Jawa Barat yang terdiri dari UMKM dan usaha yang dirintis sendiri yang berada di wilayah Kota Bogor, antara lain dari Bogor tengah, Bogor Barat, Bogor Timur, Bogor utara dan Bogor selatan dan sekitarnya. Adapun daftar peserta pengabdian kepada masyarakat, dapat dilihat pada table 3 (tiga) di atas.

Peserta dari Tim kami yang menyampaikan materi dengan tema "Pelaporan Keuangan UMKM berbasis ETAP dan Android terdiri dari: Dr.Syahril Djaddang, S.E.,M.Si.,Ak.,CA., Susilawati, S.E., M.Ak., Dr.M.Ardiansyah Syam, S.E.,Ak.,CA.,CPA., Moderator: Dr.Sailendra,SE.,M.Ak., Dosen Pendamping Nara Sumber: Nungki Puspita,S.E.,M.M., Mahasiswa Pendamping: Monang Tampubolong,S.E.,M.Ak. Sedangkan pendidikan dan usia peserta, yakni jenis atau jenjang pendidikan peserta dari Koperasi dan UMKM Kota Bogor yang bervariasi dari tingkat SMA/SMK, D3, S1, dan S2. Sebagian besar adalah dari SMA/SMK dan S1. Dengan latar belakang Pendidikan yang cukup tinggi, diharapkan peserta dapat menerima dan memahami materi yang disampaikan oleh narasumber dengan cukup baik. Usia peserta adalah berkisar antara 29 tahun hingga 69 tahun. Sebagian besar berusia 40 tahun sampai dengan 60 tahun. Sedangkan jenis usaha terdiri dari: UMKM Kuliner, UMKM Souvenir, dan lainlain. Pertanyaan yang disampaikan peserta dari Koperasi dan UMKM cukup banyak, hal ini menunjukkan perhatian yang besar untuk meningkatkan kemampuan mereka dalam melaksanakan pelaporan keuangan berbasis ETAP dan Android. Tentunya animo yang besar ini patut dihargai karena dapat meningkatkan penerimaan pajak di daerahnya, khususnya dari Kota Bogor, Jawa Barat. Beberapa pertanyaan yang kami rangkum adalah mengenai:

- Pelaporan Laba Rugi UMKM, dan pemotongan pajak.

- Bagaimana cara melaporkan laporan keuangan, omset bulanan dan tahunan.

- Permasalahan bahwa tidak setiap UKM mempunyai dan mampu menggunakan alat komputerisasi. sehingga masih banyak yang manual.

Sehingga masih perlu pengetahuan cara melaporkan catatan keuangan harian/bulanan/tahunan secara manual.

Berdasarkan jawaban yang disampaikan oleh nara sumber dan pendamping narasumber, diharapkan dapat memberikan edukasi dan solusi atas permasalahan yang dihadapi oleh peserta.
Pelatihan bagi pelaku ekonomi Koperasi dan UMKM telah dilaksanakan melalui kerjasama antara Sekolah Pascasarjana Universitas Pancasila dan Dinas Koperasi Kota Bogor. Adapun materi pelatihan, yaitu; Akuntansi UMKM berbasis ETAP, Pengenalan Software Koperasi yang terdiri dari (Tutorial KSP - Angsuran Pinjaman Bebas 5. Tutorial KSP - Angsuran Pinjaman dengan Pembayaran Transfer Antar Bank, Tutorial KSP - Angsuran Pinjaman Kolektif Bank, Tutorial KSP - Angsuran Pinjaman Kolektif Tunai, Tutorial KSP - Angsuran Pinjaman Kolektif Tunai dengan Import Data Excell, Tutorial KSP - Angsuran Pinjaman Menggunakan KSP Android Collector, dan Akuntansi UMKM berbasis android.

Outline materi Akuntansi UMKM berbasis ETAP dan android disampaikan kepada pelaku UMKM di Kota Bogor, berikut ini:

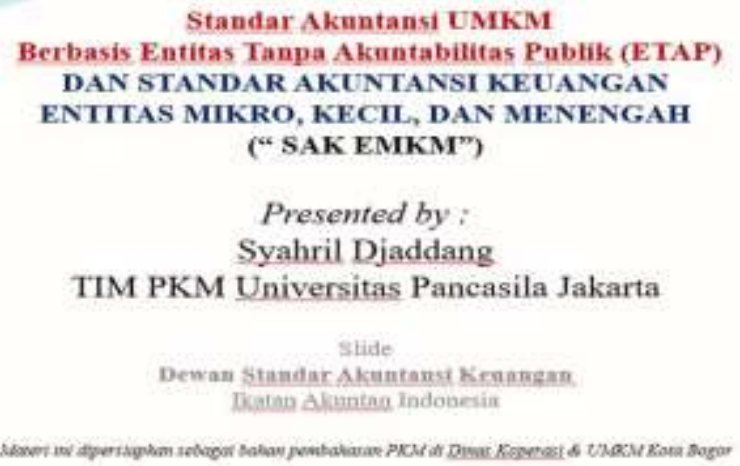

Gambar 1; Judul Materi Pelatihan

Sedangkan materi akuntansi UMKM berbasis android yang sudah dibukukan dan disampaikan kepada pelakU UMKM di Kota Bogor, berikut ini:

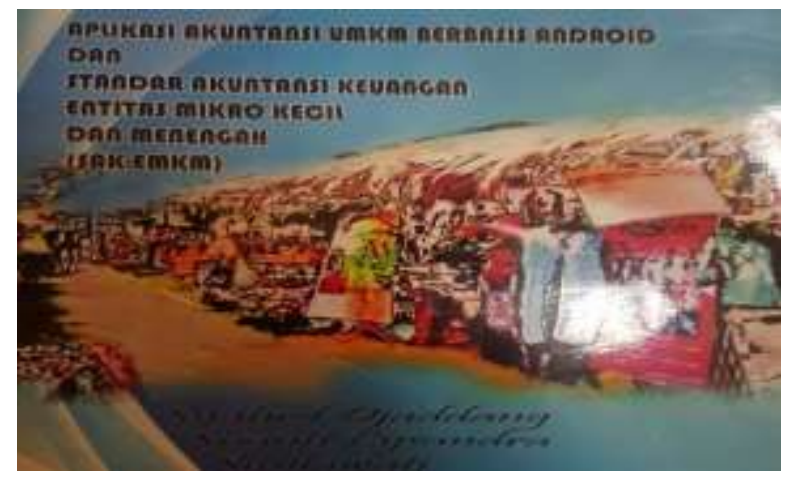

Gambar 2: Buku Akuntansi UMKM Berbasis EMKM dan Android

Sedang lokasi pelatihan kepada pelaku UMKM di aula Dinas Koperasi Pemerintah Kota Bogor. Pelaksanaan kegiatan PKM dilaksanakan oleh Tim PKM sebanyak 6 Orang, 3 Orang dari 
dosen Pasca, 2 Orang dosen FEB \& Fakultas Pariwisata dan 1 org mhs. Kegiatan PKM 2 kali, kunjungan pertama tim sebanyak 6 Orang di Kota Bogor \& selanjutnya di Kota Tangerang (Tentatif sesuai kondisi tahun Vaksinasi 2021). Dokumentasi Pelaksanaan Kegiatan PKM dapat dilihat pada gambar 3 di bawah ini:

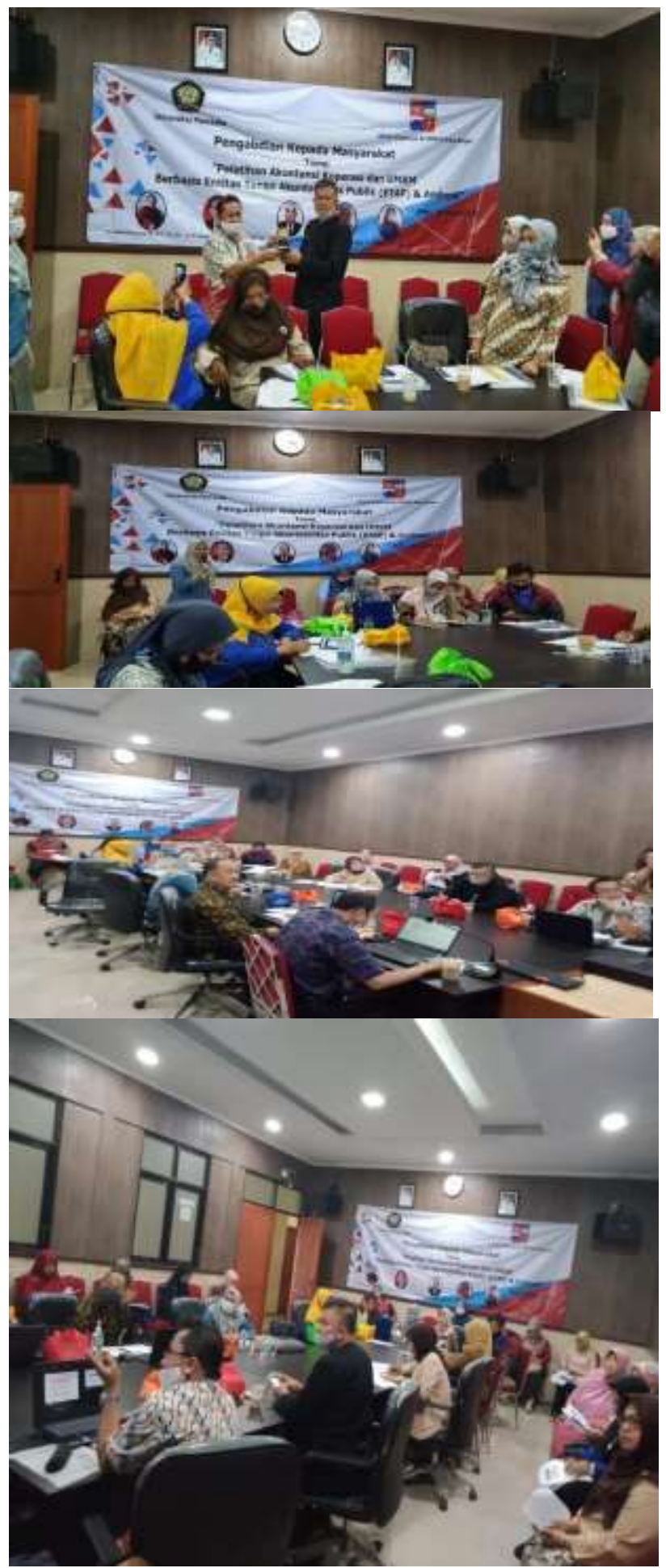

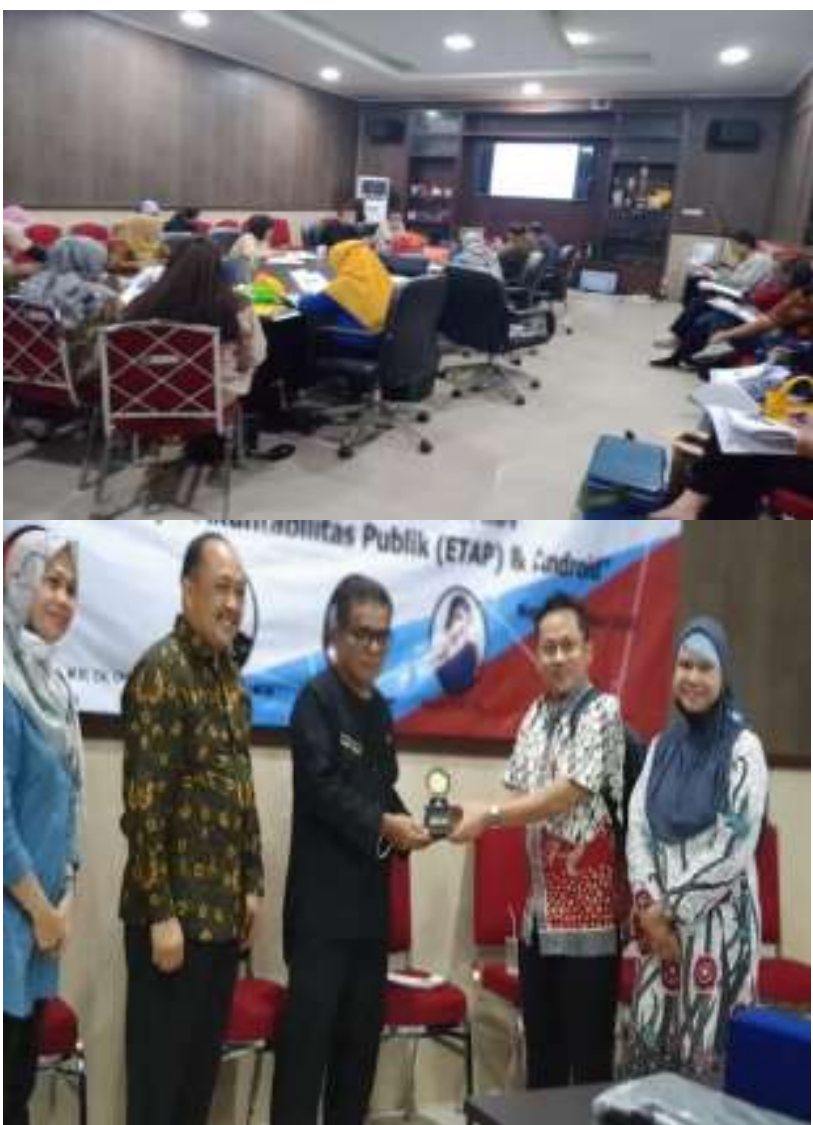

Gambar 3; Dokumentasi Pelaksanaan Kegiatan PKM

\section{KESIMPULAN}

Dalam situasi pandemi Covid 19 saat ini, pelaksanaan kegiatan pengabdian kepada masyarakat di bidang ekonomi pada UMKM dan Koperasi dengan topik Pelaporan Keuangan UMKM berbasis ETAP dan Android mendapat sambutan yang sangat baik dari Koperasi dan UMKM di Kota Bogor Jawa Barat. Walaupun kegiatan ini dilaksanakan dengan tatap muka dengan protokol Kesehatan dan kunjungan ke tempat pengabdian kepada masyarakat ini dilaksanakan, peserta terlihat sangat antusias mengikuti acara ini. Kegiatan ini tentunya dapat ditindaklanjuti di masa mendatang untuk memberikan solusi atas permasalahan yang dihadapi masyarakat dalam hal pelaporan keuangan Koperasi dan UMKM berbasis ETAP dan Android. Berdasarkan pembahasan sebelumnya, dapat disimpulkan bahwa:

1) Berdasarkan pengamatan tim pengabdian masyarakat, Kota Bogor memiliki potensi yang cukup besar dalam menyumbang pendapatan negara dari sektor pajak. Kota Bogor 
merupakan salah satu yang memiliki jumlah Koperasi dan UMKM terbanyak di Jawa Barat.

2) Potensi pajak dari Kota Bogor, yang berasal dari Koperasi dan UMKM dapat terus didorong dan ditingkatkan dengan memberikan pengetahuan dan pemahamanyang lebih baik mengenai ketentuan khususnya dengan Pelaporan keuangan koperasi dan UMKM Berbasis ETAP dan android.

3) Berdasarkan hasil kuesioner, minat pengurus koperasi dan pelakU UMKM untuk memperbaiki sistem pelaporan keuangan koperasi dan UMKM berbasis ETAP dan Android cukup besar dan dapat ditindaklanjuti dikemudian hari dengan pelatihan-pelatihan selanjutnya sesuai dengan kebutuhan UMKM dan Koperasi di Kota Bogor, Jawa Barat.

\section{SARAN}

Beberapa saran yang dapat kami sampaikan berkaitan dengan kegiatan pengabdian masyarakat ini, antara lain adalah berikut ini:

1. Kerjasama dengan Dinas Koperasi dan Usaha Kecil dan Menengah Kota Bogor perlu untuk terus dijalin dan ditingkatkan, sehingga pelatihan dan pendampingan dapat terus dilakukan secara rutin kepada pelakU UMKM dan Koperasi di Kota Bogor.

2. Pihak dari Sekolah Pasca sarjana, FEB dan Fak Pariwisata Universitas Pancasila/Tim

Pengabdian kepada Masyarakat dapat mengundang pihak Dinas Koperasi dan Usaha Kecil dan Menengah Kota Bogor untuk berdiskusi guna mengetahui lebih jauh mengenai kebutuhan pelatihan atau pendampingan bagi para pelaku usaha UMKM dan Koperasi di Kota Bogor, sehingga dapat membantu dan mencari solusi agar potensi ekonomi di daerah tersebut dapat berkembang dan ditingkatkan lagi.

3. Bekerjasama dengan Dinas Koperasi dan Usaha Kecil dan Menengah Kota Bogor memberikan pelatihan dan pendampingan kepada pelaku UMKM dan Koperasi untuk mengadakan pelatihan Pembukuan Akuntansi Sederhana Usaha Mikro \& Aplikasi Keuangan UKM, Membuat Laporan Keuangan Sederhana, pembuatan laporan keuangan Koperasi dan UMKM.

4. Tim Pengabdian kepada Masyarakat bersamasama dengan pihak Dinas Koperasi dan Usaha Kecil dan Menengah Kota Bogor dapat bersama-sama memberikan motivasi bagi UMKM dan Koperasi yang belum berkembang dan tidak aktif untuk kembali meningkatkan kegiatan usahanya.

\section{PUSTAKA}

Abeng, Tanri. (2015). Badan Usaha Milik Rakyat (BUMR), Lembaga Pelaku Ekonomi dan Keuangan Inklusif, Jakarta. Elexmedia Gramedia Group

Antaranews.com. (2020a). DPRD Kota Bogor dukung UMKM tetap eksis saat pandemi Covid-19. Retrieved February 24, 2021, from https://megapolitan.antaranews.com/berita /123548/dprd-kota-bogor-dukung-umkmtetap-eksis-saat-pandemi-covid-19

Antaranews.com. (2020b). Kemenkeu Paparkan Dampak Covid-19 Bagi daya tahan UMKM. Retrieved February 19, 2021, from https://www.antaranews.com/berita/184172 4/kemenkeu-paparkan-dampak-covid-19bagi-daya-tahan-umkm

A.Triantoko, (2015) Evaluasi Penerapan Standar Akuntansi Keuangan Entitas Tanpa Akuntabilitas Publik Pada Perusahaan Jasa Restoran (Studi Kasus Pada CÂ'Bezt Fried Chicken.

BPS Kota Bogor. (2020). Kota Bogor Dalam Angka 2020. Retrieved February 18, 2021, from https://bogorkota.bps.go.id/publication/2020 /04/27/8be591177823581 bbbf06bbb/kotabogor-dalam-angka-2020.html

Direktorat riset dan Pengabdian Masyarakat,

Direktorat Jendral Penguatan Riset dan Pengembangan Kementerian Riset, Teknologi, dan Pendidikan Tinggi (2018) Panduan Penelitian dan pengabdian Masyarakat Edisi XII.

E Kristanto, Penerapan standar akuntansi keuangan untuk entitas tanpa Akuntabilitas Publik (Sak-Etap) pada UMKM pengrajin Rotan di Desa Trangsan Kecamatan Gatak.

H. Ahya, (2017) Faktor-faktor yang mempengaruhi pelaporan keuangan berdasarkan sak etap pada UMKM sektor makanan dan minuman di kota.

Hayu Lestari, (2015). Penerapan Standar Akuntansi Keuangan Entitas Tanpa Akuntabilitas Publik (Sak Etap) Pada Ukm (Studi Pada UKM Rezzen Bakery \& Coffee.

PikiranRakyat.com. (2021b). Digitalisasi UMKM Bantu Pulihkan Perekonomian, Cepat Terealisasi Jika Masyarakat Peduli Kesehatan. Retrieved February 25, 2021, from https://www.pikiran-rakyat.com/nasional/pr01 1035025/digitalisasi-umkm-bantu-pulihkan- 
perekonomian-cepat-terealisasi-jika-

masyarakat-peduli-kesehatan

RP Hastuti, A Wijayanti, Y Chomsatu (2017).

Pengaruh Jenjang Pendidikan Dan

Pemahaman Teknologi Informasi Terhadap

Penyajian Laporan Kevangan Berdasarkan Sak Etap.

Sailendra, S., Syahril Djaddang., M. Ardiansyah Syam., Susilawati4., Nungki, P (2021). Tatakelola Keuangan UMKM Berbasis Android Untuk Meningkatkan Efisiensi dan Kinerja Usaha pada Era Covid-19 dan Normal Baru,: CAPACITAREA : Jurnal Pengabdian kepada Masyarakat Universitas Pancasila, Volume 2 (2020): 1-5; DOI:

https://doi.org/10.30874/capacitarea.2019.1

Satari, dan As'ad (2018). Strategy of Entrepreneurship and Creative Economy Development through district Mapping in Bandung City. Journal of Visual Art and Design, 10(2), 93-100.

S.Pratiwi D Tituk, (2011) Standar akuntansi keuangan entitas tanpa akuntabilitas publik pada Usaha Kecil Dan Menengah,

Syam, M. A., Djaddang, S., Salim, F., \& Rachbini, W. (2020). Kick Off Peningkatan Potensi Ekonomi Kreatif Masyarakat Melalui Koperasi, Bumdes dan UKMBerbasis Kearifan Lokaldi Kabupaten Soppeng. Capacitarea, 1 (1), 1-11. Retrieved from

http://journal.univpancasila.ac.id/index.php/ CAPACITAREA/article/view/1340 